\title{
АПАРАТНО-ПРОГРАМНІ ЗАСОБИ РОЗПІЗНАВАННЯ ЛЮДСЬКӦ̈ АКТИВНОСТІ В МЕДИЦИНІ
}

Анотація: Розглядаються існуючі системи розпізнавання активностей людини з точки зору можливості їх застосування в медицині. Основними критеріями є вартість, конфіденційність, портативність пристроїв та якість розпізнавання.

Ключові слова: засоби розпізнавання активностей людини, системи реального часу, ідентифікація.

\section{Постановка задачі}

Розпізнавання людської активності стало популярною областю досліджень протягом останніх років. Це важлива і складна технологія, яка може стати основою для багатьох нових застосувань: у розумних будинках, системах інформування для офрісних працівників, системах спостереження та інтерактивних іграх, інтерфейсах до домашньої охорони здоров'я та медичних системах. Розпізнавання людської активності є багатопрофільною областю досліджень, яка тісно зв'язана з теорією машинного навчання, штучного інтелекту, машинного сприйняття, взаємодією людини з комп'ютером, а також психологією і соціологією. Область даної роботи сфокусована саме на медичному застосуванні технології розпізнавання активності.

Мета системи розпізнавання активності - визначити (розпізнати) активності (дії чи діяльність) своїх користувачів, ненав'язливо спостерігаючи за поведінкою людей і характеристиками їх оточуючого середовища; за результатами цих спостережень - вжити необхідних заходів у відповідь. Метою розробки є забезпечення своєчасного прийому ліків за допомогою апаратно-програмного комплексу.

\section{Огляд існуючих аналогів}

3 появою мініатюрних сенсорів, які можуть бути закріплені на тілі, з'явилася можливість збирати і зберігати дані про різні аспекти діяльності людини під час щоденних справ. Ця технологія має великий потенціал для використання в автоматизованих системах моніторингу щоденних дій, які виконують безперервний запис тілесних рухів протягом тривалих періодів часу. Така система моніторингу залежать від алгоритмів розпізнавання, які можуть ефективно інтерпретувати покази датчиків і розпізнавати різні активності.

(C) Т.А. Ліхоузова, В.О. Слюсаренко, 2015 
Перший крок на шляху до досягнення мети - розпізнавання повсякденної діяльності - оснащення системи розпізнавання датчиками. Існуе три загальновідомі підходи: система на основі відео спостережень, на основі датчиків, розміщених у навколишньому середовищі та на основі датчиків, що знаходяться на тілі.

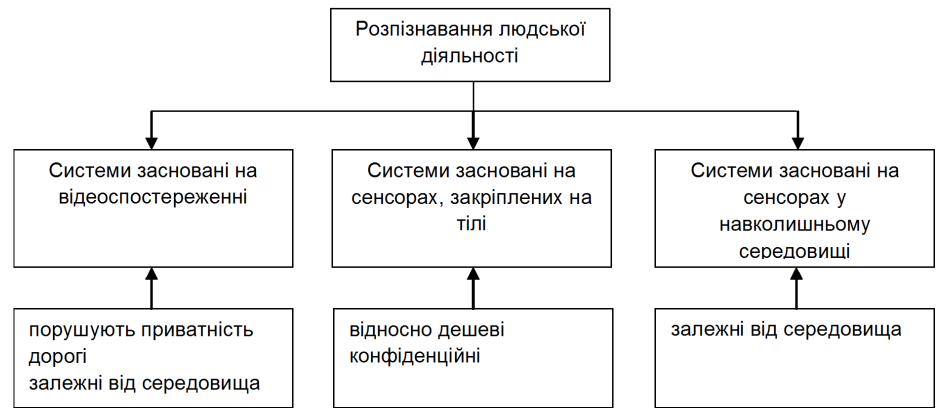

Рис. 1 - Різновиди систем розпізнавання

Датчики, що розміщені на тілі, добре підходять для збору даних про шаблони щоденних фрізичних активностей протягом тривалого періоду часу. Такі системи можуть бути розміщені на одязі $[1,2]$, ювелірних виробах [3], або як інші пристрої, що людина може носити з собою. Оскільки вони закріплені на користувачах, вони не залежать від середовища, і можуть вимірювати фізіологічні параметри, які не можуть бути виміряні, використовуючи датчики, розміщені у середовищі або відеодатчики. Крім того, такі датчики $є$ недорогими i, на відміну від відеодатчиків, не несуть загрози конфіденційності користувача.

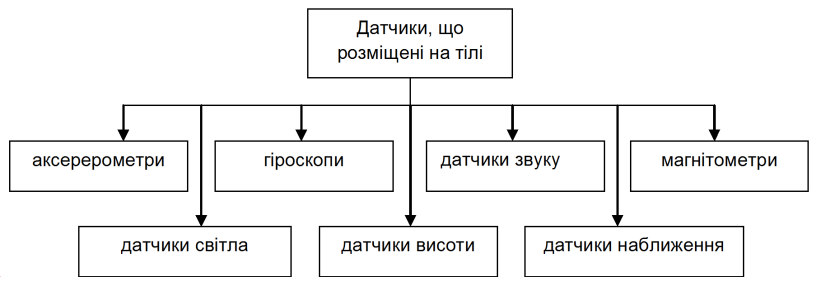

Рис. 2 - Різновиди датчиків

Оскільки одним із важливих обмежень є невисока вартість приладу, у даній роботі система розпізнавання активності людини розроблена із використанням акселерометра, що вимірює прискорення у трьох осях, а також датчиків наближення, заснованих на емнісній технології вимірювання відстані.

В області розпізнавання активності із використанням датчиків, закріплених на тілі, алгоритми розпізнавання можуть бути оціне- 
ні на основі складності діяльності, яку вони розпізнають. Складність діяльності може варіюватися і залежить від різних факторів, включаючи види діяльності і складність тренувальних даних, зібраних для класифікації цієї діяльності. Кількість датчиків, їх тип та розташування, що використовуються для класифікації активностей, також істотно впливають на складність алгоритму розпізнавання.

Більшість систем розпізнавання активності, розроблених у попередніх роботах, використовують багато датчиків, закріплених у різних місцях на тілі користувача $[4,5,7]$. Як згадувалося раніше, цей підхід хоча і здатен забезпечити більшу швидкість та точність розпізнавання, але не є застосовним для довгострокового моніторингу активності. Існуе дуже мало робіт, що досліджували використання одного акселерометра, що розміщений на талії. [6]. Такі системи забезпечували гарні результати розпізнавання для основних видів діяльності, таких як лежання, стояння, ходьба та біг. Тим не менш, вони не розпізнають із достатньою точність статичні активності, такі як стояння та сидіння. Більшість попередніх систем розпізнавання активності обмежили обсяг активностей невеликим набором. Мало систем дійсно розпізнають велику кількість активностей, проте, їх точність була більшою. У попередніх роботах було досліджено багато різних ознак у часовому та частотному просторі. Ознаки у частотному просторі вимагають великої кількості компонентів, щоб мати змогу розрізняти активності i, отже, вимагають високої обчислювальної потужності $[4,6]$. Проте ознаки з часового простору можна легко обчислювати в режимі реального часу $[5,6,7]$. Тим не менш, результати розпізнавання за допомогою цих ознак не мали високої точності. Ці ознаки розраховуються на великому часовому вікні, та не можуть забезпечити високу точність у розпізнаванні короткочасних рухів.

\section{Опис розробки}

Розглянемо загальний підхід до розпізнавання людської активності на основі акселерометра, що закріплений на тілі людини. Цей процес, як було сказано вище, $е$ багатостадійним, тобто його можна розділити на декілька окремих етапів. На кожному з таких етапів виконуються окреме закінчене завдання. Ці етапи включають в себе: запис сигналу з датчиків, обчислення ознак сигналів та класифікацію активності.

Люди, як правило, виконують одні і ті ж рухи у різні способи, це може призвести до значного розрізнення ознак, отриманих на основі даних датчиків, що закріплені на тілі. Таким чином, для досягнення ефективної класифрікації, виявлення ознак з високою мірою стійкості має велике значення. Хороший набір ознак повинен показувати невеликі зміни між повторами одних і тих же рухів від різних користувачів, але повинен істотно різнитися між рі- 


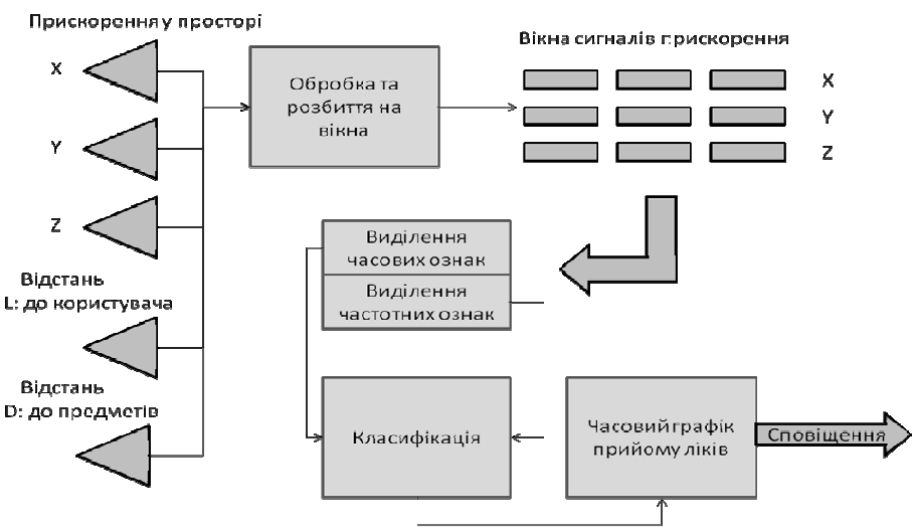

Рис. 3 - Схема роботи пристрою

зними видами діяльності. Існуе ряд методів, різної складності, які можуть були використані для вибору відповідних ознак для класифікації видів діяльності. Вони включають в себе візуальний і статистичний аналіз, щоб оцінити розподіл з використанням даної ознаки для різних видів діяльності. Візуальний метод заснований на візуальному аналізі вікон, зображених у просторі. Іншим методом відбору ознак є метод, в якому ознаки з великого набору послідовно додаються до алгоритму класифікації або видаляються з нього. Оптимальні функції ідентифікуються залежно від результатів похибки класифікації для кожної функції з набору. В якості альтернативи вибору підмножини існуючих ознак, часто можна об'єднати декілька ознак, щоб визначити нову. $Є$ дві переваги, пов'язані з такою процедурою. По-перше, часто дуже велике число ознак, може бути зменшена без втрати якості класифікації. По-друге, новий скорочений набір ознак часто має кращу роздільну здатність у просторі.

\section{Висновки}

Новизна розробленого апаратно-програмного комплексу в порівнянні з іншими системами розпізнавання активності полягає у наступному:

- Дані про щоденні активності використовуються для нагадування про своєчасне прийняття ліків.

- Використовуе емнісні сенсори наближення, що також мають дуже низький рівень споживання енергії.

- На відміну від попередніх систем, розроблена система працюе на основі мікроконтролера, що має низький рівень споживання 
енергії, i, як наслідок, низьку продуктивність у порівнянні із мікропроцесорами.

- На відміну від багатьох інших систем, що проводять класифікацію активності або не у реальному часі, або на потужному смартфоні, запропонована система проводить класифрікацію у реальному часі та безпосередньо на мікроконтролері, вбудованому у систему.

- Система є портативною та закріплена на зап'ясті руки користувача.

\section{Біблиографічний список}

1. Roy P. A possibilistic approach for activity recognition in smart homes for cognitive assistance to Alzheimer's patient. / Roy P., Bouchard B., Bouzouane A., Giroux S. - In Activity Recognition in Pervasive Intelligent Environment (Atlantis Ambient and Pervasive Intelligence), L. Chen, C. Nugent, J. Biswas, J. Hoey Editors, World Scientific Publishing Company, ISBN: 978-9078677352, pp. 1-20, September 2010

2. Iosifidis A. Person specific activity recognition using fuzzy learning and discriminant analysis / Alexandros Iosifidis, Anastasios Tefas and Ioannis Pitas - 19th European Signal Processing Conference (EUSIPCO 2011) Barcelona, Spain, August 29 September 2, 2011

3. Anguita $D$. Human activity recognition on smartphones using a multiclass hardware-friendly support vector machine / Anguita, D., Ghio, A., Oneto, L., Parra, X., Reyes-Ortiz, J.-L. - Ambient Assisted Living and Home Care; volume 7657; 216-223; 2012a

4. Kim E. Human Activity Recognition and Pattern Discovery / Kim, Eunju, Sumi Helal, and Diane Cook - PERVASIVE computing, Standards \& Emerging Technologies, Jan.-Mar., pp. 48-53.

5. Dernbach $S$. Simple and complex activity recognition through smart phones / S. Dernbach, B. Das, N. C. Krishnan, B. L. Thomas, and D. J. Cook - in Proceedings of the 8th International Conference on Intelligent Environments (IE '12), pp. 214-221, IEEE, 2012.

6. Mathie M.J. A pilot study of long term monitoring of human movements in the home using accelerometry / M. J. Mathie, A. C. F. Coster, N. H. Lovell, and B. G. Celler - J. Telemed. Telecare, vol. 10, pp. 144-151, 2004.

7. Karantonis D.M. Implementation of a real-time human movement classifier using a tri-axial accelerometer for ambulatory monitoring / D. M. Karantonis, M. R. Narayanan, M. Mathie, N. H. Lovell, and B. G. Celler - IEEE Transactions on Inf Technol Biomed, vol. 10(1), pp. 156-67, 2006. 